
Not for reproduction, distribution or commercial use.

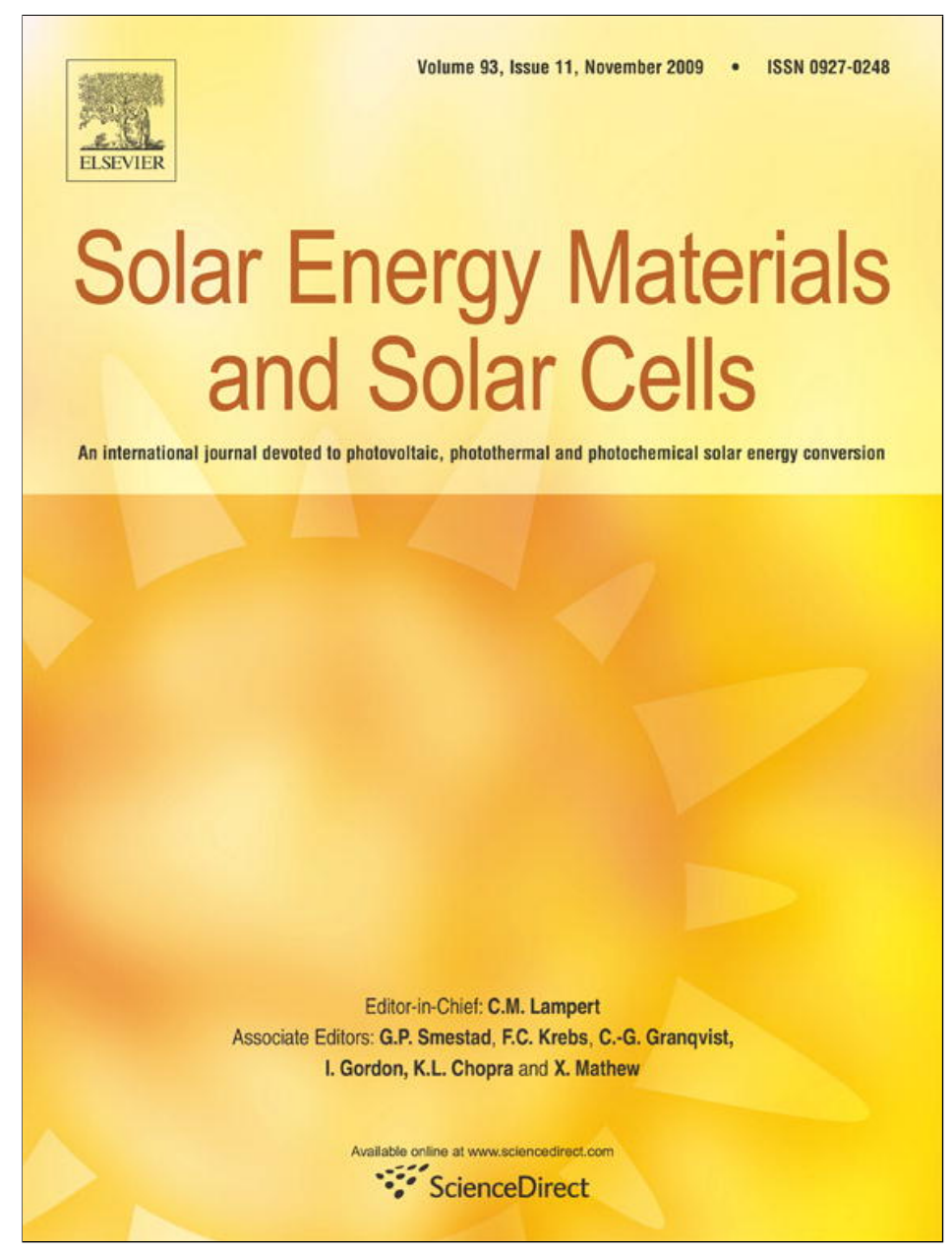

This article appeared in a journal published by Elsevier. The attached copy is furnished to the author for internal non-commercial research and education use, including for instruction at the authors institution and sharing with colleagues.

Other uses, including reproduction and distribution, or selling or licensing copies, or posting to personal, institutional or third party websites are prohibited.

In most cases authors are permitted to post their version of the article (e.g. in Word or Tex form) to their personal website or institutional repository. Authors requiring further information regarding Elsevier's archiving and manuscript policies are encouraged to visit:

http://www.elsevier.com/copyright 


\section{A round robin study of flexible large-area roll-to-roll processed polymer solar cell modules}

Frederik C. Krebs ${ }^{a, *}$, Suren A. Gevorgyan ${ }^{a}$, Bobak Gholamkhass ${ }^{b}$, Steven Holdcroft ${ }^{b}$, Cody Schlenker ${ }^{c}$, Mark E. Thompson ${ }^{c}$, Barry C. Thompson ${ }^{c}$, Dana Olson ${ }^{d}$, David S. Ginley ${ }^{d}$, Sean E. Shaheen ${ }^{\text {d,e }}$, Husam N. Alshareef ${ }^{f}$, John W. Murphy ${ }^{f}$, W. Justin Youngblood ${ }^{g}$, Nathan C. Heston ${ }^{h}$, John R. Reynolds ${ }^{i}$, Shijun Jia ${ }^{j}$, Darin Laird ${ }^{\mathrm{j}}$, Sachetan M. Tuladhar ${ }^{\mathrm{k}}$, Justin G.A. Dane ${ }^{\mathrm{k}}$, Pedro Atienzar ${ }^{\mathrm{k}}$, Jenny Nelson ${ }^{\mathrm{k}}$, Jan M. Kroon ${ }^{\text {, }}$, Martijn M. Wienk ${ }^{\mathrm{m}}$, René A.J. Janssen ${ }^{\mathrm{m}}$, Kristofer Tvingstedt ${ }^{\mathrm{n}}$, Fengling Zhang ${ }^{\mathrm{n}}$, Mattias Andersson ${ }^{\mathrm{n}}$, Olle Inganäs ${ }^{\mathrm{n}}$, Monica Lira-Cantu ${ }^{\mathrm{o}}$, Rémi de Bettignies ${ }^{\mathrm{p}}$, Stéphane Guillerez ${ }^{\mathrm{p}}$, Tom Aernouts ${ }^{\mathrm{q}}$, David Cheyns ${ }^{\mathrm{q}}$, Laurence Lutsen ${ }^{\mathrm{r}}$, Birger Zimmermann ${ }^{\mathrm{s}}$, Uli Würfel ${ }^{\mathrm{s}}$, Michael Niggemann ${ }^{\mathrm{s}}$, Hans-Frieder Schleiermacher ${ }^{s}$, Paul Liska ${ }^{t}$, Michael Grätzel ${ }^{t}$, Panagiotis Lianos ${ }^{\mathrm{u}}$, Eugene A. Katz ${ }^{\mathrm{v}}$, Wolfgang Lohwasser ${ }^{\mathrm{w}}$, Bertrand Jannon ${ }^{\mathrm{w}}$

a Risø National Laboratory for Sustainable Energy, Technical University of Denmark, Frederiksborgvej 399, DK-4000 Roskilde, Denmark

b Simon Fraser University, 8888 University Drive, Burnaby, Canada BC-V5A 1S6

' University of Southern California, Department of Chemistry, Loker Hydrocarbon Research Institute, and The Center for Energy Nanoscience and Technology, Los Angeles, CA 900891661, USA

d NREL,1617 Cole Blvd, Golden, CO 80401, USA

e Department of Physics and Astronomy, University of Denver, Denver, CO 80208, USA

${ }^{\mathrm{f}}$ University of Texas at Dallas, 800 W. Campbell Rd., Richardson, TX 75080, USA

${ }^{\mathrm{g}}$ Department of Chemistry, University of North Texas, 1155 Union Circle, \# 305070, Denton, TX 76201, USA

h Department of Physics, Center for Macromolecular Science and Engineering, Box 117200/Leigh Hall 318, University of Florida, Gainesville, FL 32611, USA

Department of Chemistry, Center for Macromolecular Science and Engineering, Box 117200/Leigh Hall 318, University of Florida, Gainesville, FL 32611, USA

j Plextronics Inc., 2180 William Pitt Way, Pittsburgh, PA 15238, USA

${ }^{\mathrm{k}}$ Blackett Laboratory, Physics Department, South Kensington, London SW7 2AZ, UK

${ }^{1}$ ECN Solar Energy, PO Box 1, Westerduinweg 3, 1755 ZG Petten, The Netherlands

${ }^{\mathrm{m}}$ Molecular Materials and Nanosystems, Laboratory of Macromolecular and Organic Chemistry, Eindhoven University of Technology, PO Box 513, 5600 MB Eindhoven, The Netherlands

${ }^{\mathrm{n}}$ Biomolecular and Organic Electronics, IFM, Center of Organic Electronics, Linköpings Universitet, S-581 83 Linköping, Sweden

${ }^{\circ}$ Centre de Investigaciò en Nanociencia i Nanotecnologia (CIN2), Campus UAB, Edifici ETSE 2nd Floor- QC/2109, Bellaterra (Barcelona) E-08193, Spain

${ }^{\mathrm{p}}$ Laboratoire Composants Solaires CEA INES-RDI, Savoie Technolac BP 332, 50 Avenue du lac Léman, 73377 Le Bourget Du Lac, France

${ }^{q}$ Organic Photovoltaics, PV Department, IMEC, Kapeldreef 75, B-3001 Leuven, Belgium

${ }^{\mathrm{r}}$ IMOMEC, IMEC, Wetenschapspark 1, B-3590 Diepenbeek, Belgium

${ }^{s}$ Department of Materials Research and Applied Optics, Fraunhofer-Institut für Solare Energiesysteme ISE, Heidenhofstrasse 2, 79110 Freiburg, Germany

${ }^{\mathrm{t}}$ Laboratory of Photonics and Interfaces (LPI), Station 6, Institute of Chemical Science and Engineering Faculty of Basic Science, Ecole Polytechnique Federale de Lausanne, CH-1015 Lausanne, Switzerland

"University of Patras, Engineering Science Department 26500 Patras, Greece

${ }^{v}$ Department of Solar Energy and Environmental Physics, J. Blaustein Institutes for Desert Research, Ben-Gurion University of the Negev, Sede Boqer Campus 84990, Israel

${ }^{\mathrm{w}}$ Alcan Packaging Singen GmbH, Alusingen-Platz 1, D-78221 Singen, Germany

\section{A R T I C L E I N F O}

\section{Article history:}

Received 10 June 2009

Received in revised form

22 July 2009

Accepted 22 July 2009

Available online 12 August 2009

\section{A B S T R A C T}

A round robin for the performance of roll-to-roll coated flexible large-area polymer solar-cell modules involving 18 different laboratories in Northern America, Europe and Middle East is presented. The study involved the performance measurement of the devices at one location (Risø DTU) followed by transportation to a participating laboratory for performance measurement and return to the starting location (Risø DTU) for re-measurement of the performance. It was found possible to package polymer solar-cell modules using a flexible plastic barrier material in such a manner that degradation of the

\footnotetext{
* Corresponding author. Tel.: +4546774799.

E-mail address: frkr@risoe.dtu.dk (F.C. Krebs).
} 
Keywords:

Round robin

Inter-laboratory study

Polymer solar cells

Roll-to-roll processed

Flexible packaging devices played a relatively small role in the experiment that has taken place over 4 months. The method of transportation followed both air-mail and surface-mail paths.

(c) 2009 Elsevier B.V. All rights reserved.

\section{Introduction}

Polymer solar cells [1-3] are a relatively recent photovoltaic (PV) technology that is believed to convincingly address the problem of reducing manufacturing cost which as a result can be expected to make a dramatic improvement in the cost factors for PV-generated power. The main reason for this lies in the ability to manufacture polymer solar cells under much more humble conditions (low temperature, no vacuum) than traditional PV technologies with a relatively small investment in capital equipment. Low temperature, solution coating and fast processing on flexible plastic substrates should enable a very low manufacturing cost which has not been fully confirmed. One study has detailed the cost of processing and shown that low-cost manufacturing of polymer solar cells is possible but materials costs must be reduced significantly to reach ultimate cost goals of 20 cents per watt [4]. The power conversion efficiency has demonstrated a consistent increase over the past 10 years and currently in excess of $6 \%$ can be obtained [5] and the current NREL certified record is $6.4 \%$ for a Konarka single junction polymer solar cell. In order to be useful as a technology it should be possible to prepare the devices using the high-speed methods with both reasonable performance and stability [3]. Since each of the properties required for successful implementation of the technology has been demonstrated individually it may seem trivial to find a materials combination and device geometry where these properties are observed at the same time. However, it has proven rather difficult to unify this into a single device. In the traditional 1st and 2nd generation photovoltaics it has been customary for decades to share devices and perform studies known as round robins (RR) or inter-laboratory studies (ILS) [6-13]. Within the realm of polymer photovoltaics devices have rarely been shared and few examples exist where devices have been deliberately transported between laboratories $[14,15]$. The only well-documented examples include the certification of efficiency and measurement of record devices at a reference laboratory (e.g. NREL, AIST, Frauenhofer ISE) to support the claims of high performance $[5,16]$. The main reason for this can be ascribed to the relatively poor stability that polymer solar cells have exhibited to date. Degradation can at worst be so rapid that transportation would be impossible without complete degradation of the device [1]. This has made it difficult to compare results between laboratories and it has become customary not to think of sharing cells and measurements. An additional problem that has arisen is some inconsistencies in reported data that possibly could have been avoided if it had been possible to get a second opinion from one or more collegial laboratories. This has resulted in some debate [17-20]. The RR (or ILS) has traditionally been employed to serve the purpose of transporting the same reference devices and calibration equipment such that a very high level of agreement on measurement conditions and measured data is achieved. This was excellently demonstrated in the 1980s and 1990s by many laboratories [6-11]. RR and ILS can also be more humbly applied to test whether it is at all possible to share devices for a given technology.

In this study we show that it is possible to encapsulate flexible polymer solar-cell devices in such a way that RR and ILS are possible. We discuss some of the requirements to the polymer solar-cell device that will need to be fulfilled before RR and ILS can be performed with the high level of quality that is currently customary within the field of 1 st and 2nd generation photovoltaics.

\section{Experimental}

\subsection{Device preparation and handling}

The devices were prepared following the method described in the literature except that full roll-to-roll processing was employed in all steps such that also the final silver electrode was printed using a roll-to-roll process [21]. Briefly, the device was prepared starting from a commercially available $130-\mu$ m-thick PET substrate with an overlayer of ITO having a nominal sheet resistivity of $60 \Omega$ square $^{-1}$. The desired ITO pattern was developed by screen printing and UV curing an etch resist with the desired pattern followed by etching, stripping, washing and drying. A zinc oxide nanoparticle layer was then applied by a modified slot-die coating procedure [22] followed by deposition of P3HT-PCBM and PEDOT:PSS layers using the same method. The devices were completed by screen-printing silver paste. The layered architecture of the device was thus PET-ITO-ZnO-P3HT:PCBM-PEDOT:PSS$\mathrm{Ag}$ paste. Single cells as well as 2, 3 and 8 serially connected devices were prepared. The modules with 8 serially connected devices were employed in this study. The devices were labelled according to the position they had on the roll. A photograph of the typical device is shown from the backside in Fig. 1.

\subsection{Device encapsulation}

After drying a $25-\mu \mathrm{m}$-thick PET protective layer was laminated on top of the active stack in the device. This layer served the purpose of protecting the active layer during handling. The thin PET had little barrier properties. The devices in this form were

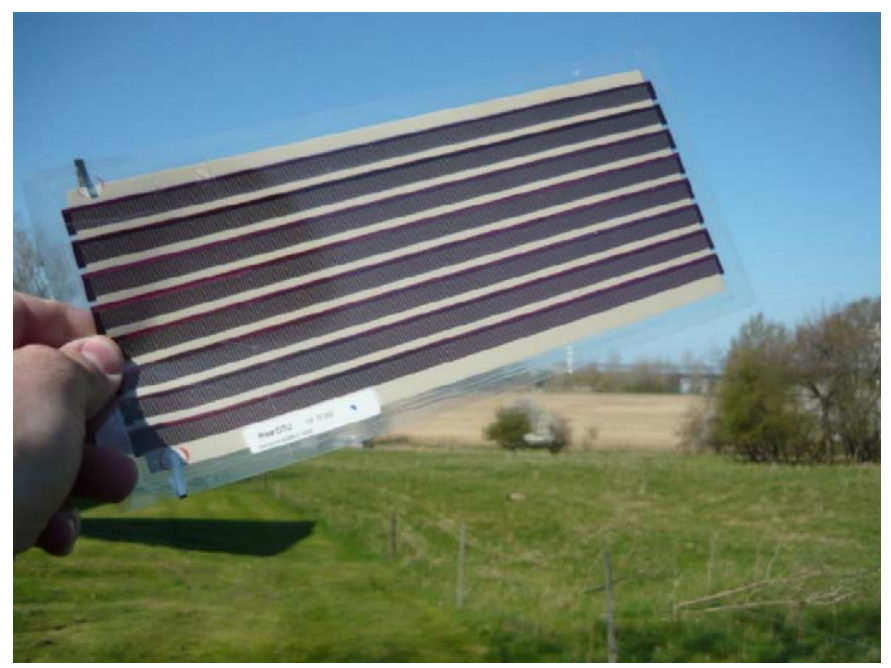

Fig. 1. The modules employed in this study as seen from the back side. The module comprises 8 serially connected devices. 
quite stable on storage in the dark under ambient conditions $\left(20 \pm 5{ }^{\circ} \mathrm{C}\right.$ and $35 \pm 5 \% \mathrm{rh}$ ). The devices could be characterised in this "unprotected" form and had an operational stability sufficient for characterisation while the T80 was typically less than $1 \mathrm{~h}$ $\left(1000 \mathrm{Wm}^{-2}, \mathrm{AM} 1.5 \mathrm{G}\right)$. In order to protect the devices, a commercially available barrier material from Alcan Packaging was employed. The barrier foil is based on PET and has a UV-filter incorporated. The barrier performance was $<0.01 \mathrm{~cm}^{3} \mathrm{~m}^{-2} \mathrm{bar}^{-1}$ day $^{-1}$ with respect to oxygen (measured according to ASTM D $3985-81$ ) and $0.04 \mathrm{~g} \mathrm{~m}^{-2}$ day $^{-1}$ with respect to water vapour (measured according to ASTM F 372-78). The barrier foil thickness was $55 \mu \mathrm{m}$. To encapsulate devices a pressure-sensitive adhesive was applied to the foil and then laminated first on the front side of the module and then on the backside. Holes were punched in the backside to allow for making contacts with the silver bus. Electrical contacts to flexible circuits are problematic and rarely suitable for multiple contacting and re-contacting. In this case tinned copper strips were applied by direct soldering using a soldering iron with a tip temperature of $410^{\circ} \mathrm{C}$ using the minimal amount of contact time possible. After soldering the contacts were mechanically decoupled by application of Mylar tape.

Several groups experienced problems with these contacts and a more reliable contacting scheme will have to be developed in the future. A rim of approximately $1 \mathrm{~cm}$ was kept around the edges of the device module that had dimensions of $25 \mathrm{~cm} \times 10.7$ $\mathrm{cm}$. The total module area was $267.5 \mathrm{~cm}^{2}$ and the nominal active area as defined by the overlap between the PEDOT:PSS and ITO electrode was $120 \mathrm{~cm}^{2}$. Immediately after encapsulation the devices were consistently observed to drop significantly in performance, though they would quickly recover and improve in performance to a level better than before encapsulation. All devices were then annealed under the solar simulator by scanning $I-V$ curves until a constant performance was obtained. This typically took less than $2 \mathrm{~h}$ and sometimes as little as $15 \mathrm{~min}$ as shown in Fig. 2. All devices exhibited this effect. After a constant performance had been reached the devices were sent out to the selected research groups. All devices were shipped using ordinary mail in Europe and the Middle East and Courier service was used

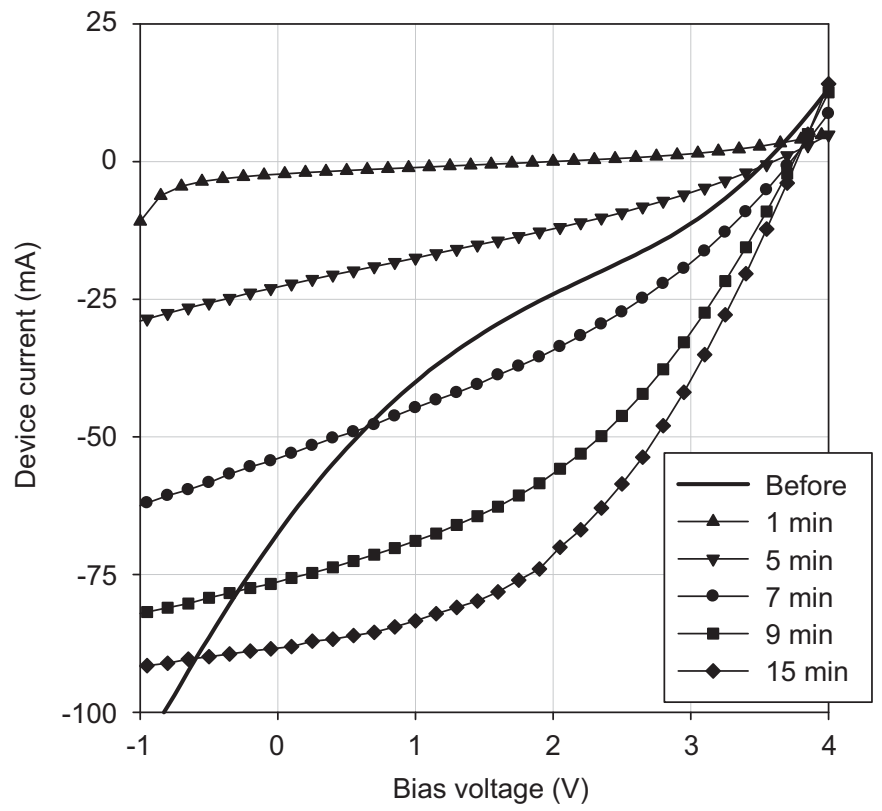

Fig. 2. The $I-V$ behaviour before lamination (solid curve) and the very large decrease in performance observed upon lamination followed by improvement during continuous illumination $\left(1000 \mathrm{~W} \mathrm{~m}^{-2}, \mathrm{AM} 1.5 \mathrm{G}, 72^{\circ} \mathrm{C}\right)$ for an 8 stripe module (module no. CR 79 081). in shipping (implying air freight) to Northern America. No knowledge of the transport condition for each module is available.

\subsection{Device measurements}

The modules were sent to the many different laboratories participating (Table 1) in this study and a list of rough guidelines was provided on how it would be desirable to record measurements on the devices:

(1) Placing the solar cell under the simulator for 1 min with open circuit prior to measurements.

(2) Recording the temperature of the device during the measurement.

(3) Recording the $I-V$ curves from $-1 \mathrm{~V}$ to $+5 \mathrm{~V}$ in steps of $50 \mathrm{mV}$ at a speed of $10 \mathrm{~ms}$ per step. The $I-V$ curve measurements could be repeated to establish if the readings are consistent.

(4) Returning the cell for repetition of the measurements to establish whether the transport has damaged the devices.

Due to the many different conditions employed for this study by the many participants no specific detail is given beyond what is stated in Tables 1 and 2 . In relation to measurements carried out in Israel a specific comment is given below due to its close match to the AM1.5G spectrum (ASTM G173). In Sede Boqer (in the Negev Desert, Israel, lat. $30.8 \mathrm{~N}$, lon. $34.8 \mathrm{E}$, alt. $475 \mathrm{~m}$ ), the outdoor $I-V$ measurements were performed on cloudless days, during noontime, at normal incidence to the incoming solar-beam radiation. The solar irradiance, measured with a calibrated thermopile pyranometer (Eppley PSP), was found to remain constant, during the test runs, to within approximately $\pm 0.3 \%$ at levels that slightly exceeded $1000 \mathrm{~W} / \mathrm{m}^{-2}[14,15,23]$. The study was prompted by the fact that due to a fortunate coincidence of atmospheric effects at this particular site, the noontime spectrum on cloudless days is always extremely close [23,24] to the standard AM 1.5G spectrum when compared to any solar simulator. The closeness of the ambient spectra to that of AM $1.5 \mathrm{G}$ indicates that no significant spectral corrections need be performed on the Sede Boker outdoor measurements. Because the outdoor solar irradiance level in Sede Boker was not, in general, precisely equal to $1000 \mathrm{~W} / \mathrm{m}^{-2}$, it was necessary to adjust the measured values of short-circuit current, $I_{\mathrm{sc}}$, current at the maximum power point, $I_{\mathrm{mpp}}$, and maximum output electrical power, $P_{\text {out }}$, to the standard test irradiance value. Previous studies $[14,15,23]$ give us confidence that no substantial errors would be introduced into our results by linearly adjusting measurements performed at, say, $1031 \mathrm{~W} / \mathrm{m}^{-2}$, to the standard $1000 \mathrm{~W} / \mathrm{m}^{-2}$ level (Table 2). During the $I-V$-curve measurements, the cells had ambient temperatures measured by a T-type thermocouple.

All devices were manufactured on 27 January 2009, laminated and characterised on 19 February and shipped to all participants on 20 February 2009. Some of the participating laboratories did not have the possibility of illuminating the relatively large module evenly and instead used the Sun as a source of light. This led to some differences in the measured parameters due to relatively large temperature differences. The devices show a significant dependence on temperature and incident light intensity. The data for all the cells are listed in Table 2. The solar simulation at Risø DTU was carried out with a Steuernagel Solarkonstant KHS575 for all characterisation $\left(1000 \mathrm{Wm}^{-2}, \mathrm{AM} 1.5 \mathrm{G}, 72^{\circ} \mathrm{C}, 40 \% \mathrm{rh}\right)$. The AM1.5G reference spectrum was according to ASTM G173. Accelerated lifetime measurements using hard UV-irradiation were carried out with a Steuernagel Solarkonstant KHS1200 $\left(1000 \mathrm{~W} \mathrm{~m}^{-2}\right.$, no UV-filter, $72{ }^{\circ} \mathrm{C}, 40 \% \mathrm{rh}$ ). Distinct yellowing of the 
Table 1

A map showing the participating laboratories and a table of their position (in WGS84 coordinates) and the dates of receipt and completion of the study.

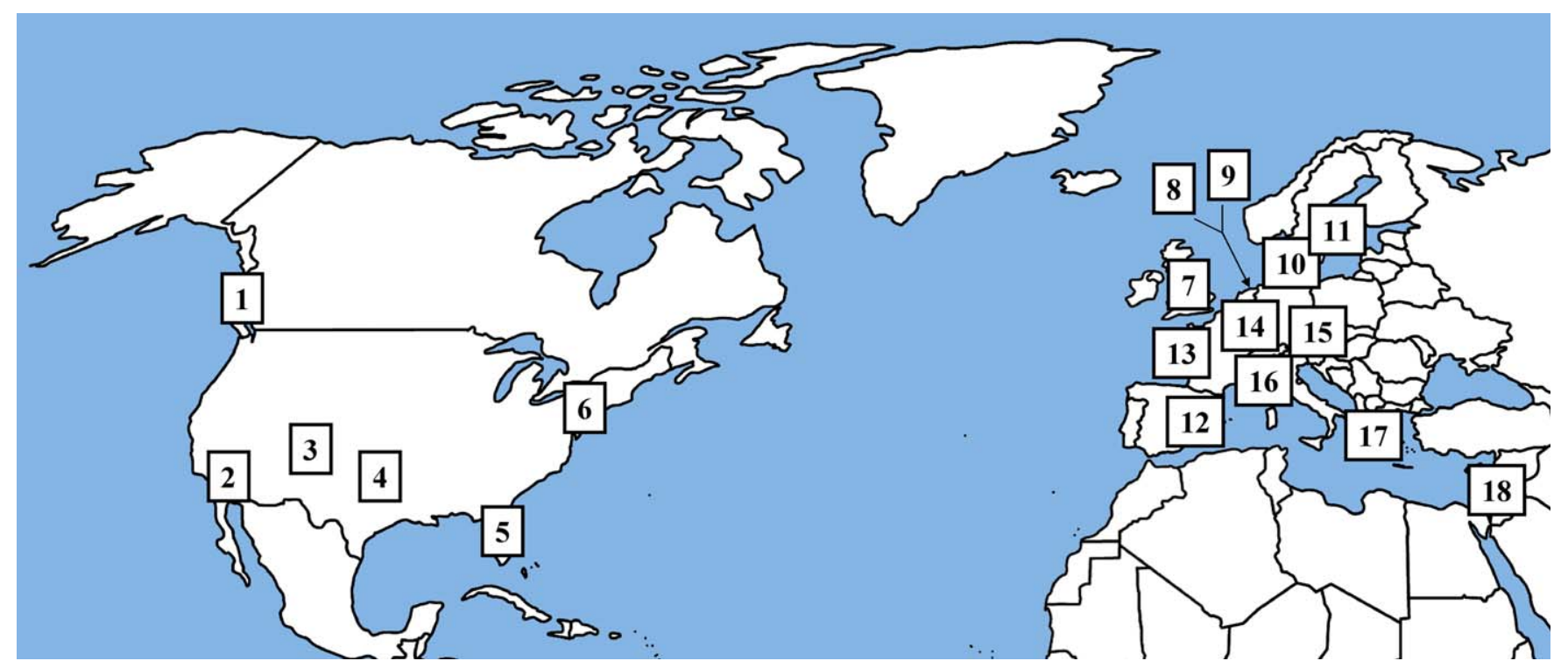

\begin{tabular}{|c|c|c|c|c|c|c|}
\hline Number & Group leader (laboratory name) & Country & Lattitude and longitude & Date of study & Date completed & $\begin{array}{l}\text { Number of } \\
\text { days to } \\
\text { completion }\end{array}$ \\
\hline 1 & Steven Holdcroft (SFU) & Canada & $49^{\circ} 16^{\prime} \mathrm{N} / 122^{\circ} 55^{\prime} \mathrm{W}$ & 07 April & 27 April & 67 \\
\hline 2 & Barry C. Thompson (USC) & United States & $34^{\circ} 1^{\prime} \mathrm{N} / 118^{\circ} 17^{\prime} \mathrm{W}$ & 05 May & 15 May & 85 \\
\hline 3 & David S. Ginley (NREL) & United States & $39^{\circ} 44^{\prime} \mathrm{N} / 105^{\circ} 12^{\prime} \mathrm{W}$ & 30 March & 12 June & 113 \\
\hline 4 & W. Justin Youngblood (UNT) & United States & $33^{\circ} 12^{\prime} \mathrm{N} / 97^{\circ} 8^{\prime} \mathrm{W}$ & 12 May & 02 June & 103 \\
\hline 5 & John R. Reynolds (UFL) & United States & $29^{\circ} 38^{\prime} \mathrm{N} / 82^{\circ} 20^{\prime} \mathrm{W}$ & 29 March & 27 April & 67 \\
\hline 6 & Darin Laird (Plextronics) & United States & $40^{\circ} 26^{\prime} \mathrm{N} / 79^{\circ} 58^{\prime} \mathrm{W}$ & 11 March & 26 March & 36 \\
\hline 7 & Jenny Nelson (Imperial College) & United Kingdom & $51^{\circ} 29^{\prime} \mathrm{N} / 0^{\circ} 10^{\prime} \mathrm{E}$ & 16 March & 25 March & 34 \\
\hline 8 & Jan M. Kroon (ECN) & Holland & $52^{\circ} 46^{\prime} \mathrm{N} / 4^{\circ} 4^{\prime} \mathrm{E}$ & 13 March & 15 April & 55 \\
\hline 9 & René A.J. Janssen (TUE) & Holland & $51^{\circ} 26^{\prime} \mathrm{N} / 5^{\circ} 28^{\prime} \mathrm{E}$ & 08 April & 29 May & 99 \\
\hline 10 & Frederik C. Krebs (Risø DTU) & Denmark & $55^{\circ} 69^{\prime} \mathrm{N} / 12^{\circ} 10^{\prime} \mathrm{E}$ & 20 February (all) & 09 June (all) & 110 \\
\hline 11 & Olle Inganäs (LIU) & Sweden & $58^{\circ} 23^{\prime} \mathrm{N} / 15^{\circ} 34^{\prime} \mathrm{E}$ & 19 March & 30 March & 39 \\
\hline 12 & Monica Lira-Cantu (CIN2) & Spain & $41^{\circ} 23^{\prime} \mathrm{N} / 2^{\circ} 11^{\prime} \mathrm{E}$ & 26 February & 04 May & 74 \\
\hline 13 & Stéphane Guillerez (CEA/INES) & France & $45^{\circ} 34^{\prime} \mathrm{N} / 5^{\circ} 54^{\prime} \mathrm{E}$ & 27 February & 05 March & 14 \\
\hline \multirow[t]{2}{*}{14} & Tom Aernouts (IMEC) & Belgium & $50^{\circ} 51^{\prime} \mathrm{N} / 4^{\circ} 40^{\prime} \mathrm{E}$ & 28 February & 09 March & 18 \\
\hline & Laurence Lutsen (UHasselt) & Belgium & $50^{\circ} 51^{\prime} \mathrm{N} / 4^{\circ} 40^{\prime} \mathrm{E}$ & 02 April & 15 April & 55 \\
\hline 15 & Hans-Frieder Schleiermacher (ISE) & Germany & $47^{\circ} 59^{\prime} \mathrm{N} / 7^{\circ} 51^{\prime} \mathrm{E}$ & 04 June & 09 June & 110 \\
\hline 16 & Michael Grätzel (EPFL) & Switzerland & $46^{\circ} 31^{\prime} \mathrm{N} / 6^{\circ} 33^{\prime} \mathrm{E}$ & 10 March & $-{ }^{\mathrm{a}}$ & 19 \\
\hline 17 & Panagiotis Lianos (UPATRAS) & Greece & $38^{\circ} 15^{\prime} \mathrm{N} / 21^{\circ} 44^{\prime} \mathrm{E}$ & 12 March & 25 March & 34 \\
\hline 18 & Eugene A. Katz (BGU) & Israel & $31^{\circ} 15^{\prime} \mathrm{N} / 34^{\circ} 48^{\prime} \mathrm{E}$ & 19 April & 13 May & 83 \\
\hline
\end{tabular}

The devices were characterised as Risø DTU on 19 February 2009 and sent out to the participating laboratories on 20 February 2009.

a The device was destroyed during damp heat test.

PET was observed after 1 week of illumination. Devices were typically fully degraded in less than $1000 \mathrm{~h}$.

\section{Results and discussion}

\subsection{Background}

The agreement between laboratories on results obtained for a given subject of study is at the heart of our scientific and technical understanding of that subject. In the context of photovoltaics this was recognized very early in the fields of 1 st and 2 nd generation solar cells where systematic studies have been carried out over the years with careful documentation and dissemination of the results. Standards have been set up for doing this in a consistent manner and specialized procedures have been described. This ranges from methods to package devices, methods of transporting cells between laboratories to minimize risk of data loss in the event that devices are lost and circulation of reference, calibration and test devices [6-13]. In the context of polymer solar cells this has been inherently more difficult due to problems of stability of the devices during handling, storage and measurement [1]. Polymer solar cells for these reasons have been lagging significantly behind their predecessors and so far few have undertaken the sharing of devices and measurements $[14,15,25]$ but as stability has improved drastically over recent years the possibility of doing this on a regular basis exists. The research community on polymer solar cells will have to set up networks, protocols and methods to facilitate this. However, all this does not have to be done anew due to the massive body of existing work that was built 20-30 years ago. There will necessarily be some adjustments to the methodologies such that they fit the subject of polymer solar cells and these have been addressed and are being currently addressed through the international summits on OPV stability (ISOS-1 and ISOS-2) [26]. In many ways it is a highly complex task to define how the protocols and standards should be as these 
Table 2

Results from the round robin experiment on 8 stripe polymer solar cells modules with a PET-ITO-ZnO-P3HT:PCBM-PEDOT:PSS-Ag device geometry.

\begin{tabular}{|c|c|c|c|c|c|c|c|}
\hline $\begin{array}{l}\text { Laboratory } \\
\#\end{array}$ & Module & Recipient & 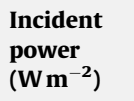 & $\begin{array}{l}\text { Temperature } \\
\left({ }^{\circ} \mathrm{C}\right)\end{array}$ & At Risø DTU & At recipient & Back at Risø DTU \\
\hline 1 & CR 79097 & $\begin{array}{l}\text { Steven } \\
\text { Holdcroft }\end{array}$ & 1100 Sun & 44 & $0.86(94.3,3.07,36 \%)$ & $0.97(98.0,3.45,38 \%)$ & $1.06(96.4,3.26,40 \%)$ \\
\hline \multirow[t]{2}{*}{2} & CR 79093 & $\begin{array}{l}\text { Barry C. } \\
\text { Thompson }\end{array}$ & 950 Sun & 24 & $1.19(102.8,3.34,41 \%)$ & $0.82(62.4,3.40,44 \%)$ & $1.30(106.79,3.43,42 \%)$ \\
\hline & & & 990 Sun & 21 & - & - & $1.43(110.47,3.71,41 \%)$ \\
\hline \multirow[t]{2}{*}{3} & CR 79109 & $\begin{array}{l}\text { David S. } \\
\text { Ginley }\end{array}$ & $\begin{array}{l}1000 \\
\text { simulated }\end{array}$ & - & $1.35(97.0,3.78,44 \%)$ & $1.12(72.8,4.0,44 \%)^{a}$ & $1.30(87.15,3.83,46 \%)$ \\
\hline & CR 79092 & $\begin{array}{l}\text { Sean } \\
\text { Shaheen }\end{array}$ & $\begin{array}{l}1000 \\
\text { simulated }\end{array}$ & - & $0.90(101.9,3.05,35 \%)$ & $0.74(77.8,3.1,34 \%)^{a}$ & $1.20(96.03,3.41,43 \%)$ \\
\hline 4 & CR 79089 & $\begin{array}{l}\text { W. Justin } \\
\text { Young- } \\
\text { blood }\end{array}$ & $\begin{array}{l}1000 \\
\text { simulated }\end{array}$ & - & $0.75(99.76,2.84,31 \%)$ & $0.86(114.5,2.81,32 \%)^{\mathrm{b}}$ & $1.38(105.86,3.7441 \%)$ \\
\hline 5 & CR 79090 & $\begin{array}{l}\text { John R. } \\
\text { Reynolds }\end{array}$ & 970 Sun & 26 & $0.96(97.9,3.16,37 \%)$ & $1.16(104.8,3.36,38 \%)$ & $1.18(104.2,3.33,40 \%)$ \\
\hline 6 & CR 79154 & Darin Laird & $\begin{array}{l}1000 \\
\text { simulated }\end{array}$ & 47 & $1.33(103.9,3.69,41 \%)$ & $1.16(100.6,3.98,35 \%)$ & $1.48(108.8,3.81,42 \%)$ \\
\hline 7 & CR 79158 & $\begin{array}{l}\text { Jenny } \\
\text { Nelson }\end{array}$ & 1000 Sun & $38-40$ & $0.65(79.07,3.07,32 \%)$ & $1.06(84.72,3.76,36 \%)$ & $1.03(86.6,3.78,38 \%)$ \\
\hline 8 & CR 79149 & $\begin{array}{l}\text { Jan M. } \\
\text { Kroon }\end{array}$ & $\begin{array}{l}1000 \\
\text { simulated }\end{array}$ & 25 & $1.28(94.1,3.71,44 \%)$ & $1.21(92.3,4.0,39.5 \%)$ & $1.13(86.8,3.71,42 \%)$ \\
\hline \multirow[t]{2}{*}{9} & CR 79074 & $\begin{array}{l}\text { R.A.J. } \\
\text { Janssen }\end{array}$ & $\begin{array}{l}1000 \\
\text { simulated }^{c}\end{array}$ & - & $1.27(118.0,3.5,37 \%)$ & $1.25(97.3,3.83,40 \%)$ & $1.38(105.86,3.74,41 \%)$ \\
\hline & CR 79091 & & & - & $1.13(102.0,3.31,40 \%)$ & $1.11(91.2,3.50,42 \%)$ & $1.07(97.35,3.31,40 \%)$ \\
\hline 10 & All & $\begin{array}{l}\text { Frederik C. } \\
\text { Krebs }\end{array}$ & $\begin{array}{l}1000 \\
\text { simulated }\end{array}$ & 72 & - & - & - \\
\hline 11 & CR 79088 & $\begin{array}{l}\text { Olle } \\
\text { Inganäs }\end{array}$ & 1000 Sun & 29 & $1.02(94.7,3.21,40 \%)$ & $0.97(87.0,3.45,39 \%)$ & $1.12(99.8,3.35,40 \%)$ \\
\hline 12 & CR 79148 & $\begin{array}{l}\text { Monica } \\
\text { Lira-Cantu }\end{array}$ & $\begin{array}{l}1000 \\
\text { simulated }\end{array}$ & $66-77$ & $1.09(95.08,3.305,41 \%)$ & $1.46(132.1,3.59,37 \%)$ & $1.08(99.62,3.22,40 \%)$ \\
\hline \multirow[t]{2}{*}{13} & CR 79095 & $\begin{array}{l}\text { Stéphane } \\
\text { Guillerez }\end{array}$ & 930 Sun & 26 & $0.89(99.42,3.09,34 \%)$ & $0.73(70.6,3.04,31.4 \%)^{d}$ & $-{ }^{\mathrm{e}}$ \\
\hline & CR 79096 & & $\begin{array}{l}1000 \\
\text { simulated }\end{array}$ & $32-35$ & $0.93(95.0,3.18,37 \%)$ & $1.13(169.2,3.64,30.5 \%)$ & $1.03(103.7,3.32,35 \%)^{f}$ \\
\hline \multirow[t]{2}{*}{14} & CR 79156 & $\begin{array}{l}\text { Tom } \\
\text { Aernouts }\end{array}$ & $\begin{array}{l}1000 \\
\text { simulated }\end{array}$ & 25 & $1.14(97.78,3.556,39 \%)$ & $1.26(102.0,3.87,38 \%)$ & $1.15(107.2,3.52,36 \%)$ \\
\hline & CR 79094 & $\begin{array}{l}\text { Laurence } \\
\text { Lutsen }\end{array}$ & & 25 & $0.76(94.98,2.95,32 \%)$ & $0.99(97.8,3.50,35 \%)$ & $1.15(104.7,3.33,39 \%)$ \\
\hline \multirow[t]{2}{*}{15} & CR 79157 & $\begin{array}{l}\text { Hans- } \\
\text { Frieder } \\
\text { Schleier- } \\
\text { macher }\end{array}$ & $\begin{array}{l}1000 \\
\text { simula- } \\
\text { ted }^{\mathrm{g}, \mathrm{h}}\end{array}$ & 35 & $1.41(106.98,3.71,42 \%)$ & $0.27(27.3,3.2,37.8 \%)^{g}$ & $0.36(43.37,2.75,36 \%)$ \\
\hline & & & $\begin{array}{l}1001.9 \\
\text { flash }\end{array}$ & 25 & - & $0.74(81.7,4.1,26.8 \%)$ & - \\
\hline 16 & CR 79111 & $\begin{array}{l}\text { Michael } \\
\text { Grätzel }\end{array}$ & $\begin{array}{l}1000 \\
\text { simulated }\end{array}$ & 55 & $1.39(100.2,3.75,44 \%)$ & $1.35(106.1,3.67,41.6 \%)^{g}$ & Destroyed $^{\mathrm{i}}$ \\
\hline 17 & CR 79110 & $\begin{array}{l}\text { Panagiotis } \\
\text { Lianos }\end{array}$ & 750 Sun & - & $1.51(121.0,3.79,39 \%)$ & $1.64(90.4,3.98,41 \%)$ & $1.30(103.4,3.81,40 \%)$ \\
\hline 18 & CR 79098 & $\begin{array}{l}\text { Eugene A. } \\
\text { Katz }\end{array}$ & 1031 Sun $^{\mathrm{j}}$ & 41 & $1.15(102.18,3.33,40 \%)$ & $1.46(119.3,3.61,41 \%)$ & $1.27(109.14,3.38,41 \%)$ \\
\hline
\end{tabular}

The modules were sent to the recipients on 20 February. The data is quoted as PCE (\%) (device current (mA), device voltage (V), fill factor (\%)). The PCE is calculated for the nominal active area of $120 \mathrm{~cm}^{2}$. The test conditions at Risø DTU were in all instances $1000 \mathrm{~W} \mathrm{~m}^{-2}, \mathrm{AM} 1.5 \mathrm{G}, 72{ }^{\circ} \mathrm{C}, 40 \% \mathrm{rh}$.

a Illuminated area $251 \mathrm{~cm}^{2}$.

b Only $80 \mathrm{~cm}^{2}$ of the active area in the device was illuminated.

c A P3HT:PCBM reference device was used.

d $930 \mathrm{~W} \mathrm{~m}^{-2}$ Sun 28 February 2009.

e Cell kept for outdoor study.

${ }^{\mathrm{f}}$ Contacts had to be cut and modified upon return.

$\mathrm{g}$ Illuminated area $10 \mathrm{~cm} \times 10 \mathrm{~cm}$.

${ }^{\mathrm{h}}$ Measured in a glovebox.

i Destroyed after $68 \mathrm{~h} 85^{\circ} \mathrm{C} / 100 \% \mathrm{rh}$, followed by $18 \mathrm{~h}$ in dry oven at $40^{\circ} \mathrm{C}$ and $19 \mathrm{~h}$ of $17 \mathrm{mmHg}$ vacuum.

j Current and PCE corrected to $1000 \mathrm{~W} \mathrm{~m}^{-2}$.

depend highly on how the technology evolves, how the users evolve and how the demands on the technology is going to evolve. Polymer photovoltaics is at the brink of commercialisation in its first forms and the need to address these questions is pertinent while little is known of the final requirements. To demonstrate the possibility and to describe how the sharing of devices can be carried out this study was undertaken.

\subsection{Choice of the method}

There are several methods by which RR or ILS can be performed and the preferred method when wishing to compare how well the participating laboratories agree is to cycle the same devices, reference devices and calibration equipment through all the participating laboratories. This method requires that all 
participants adhere to a strict time plan as delays accumulate and if the subjects are lost (during transport, due to failure or by accidental destruction) the data are incomplete. This methodology also requires that all the participants are established and familiar with the particular solar cells as a subject (e.g. shape, form, contacts, and behaviour). A simpler first approach is to have individual cells cycle back and forth between one laboratory and participating laboratories. In this method the failure of one of the links does not affect the group. The limitation is that the accuracy is an arbitrary relation between one single laboratory and the participating laboratories. In this case the purpose was to test if it was at all possible to send devices around and obtain meaningful data upon return. For these reasons the simple method was chosen as a first approach. Seen in hindsight this was the most rational decision as the study took $>1300$ days in total $(>3$ years). A cyclic study would thus have been almost impossible to complete and it should be stressed that all participating laboratories in a RR or ILS should first qualify and exhibit reasonable readiness needed for the timescale of the experiment.

\subsection{Choice of participating laboratories}

Ideally representative laboratories from all countries should enter a study of this kind. This has proven far from possible and as is evident from Table 1 the participants are concentrated in North America, Western Europe and the Middle East. It would have been desirable to include participants from the southern hemisphere and from Central and East Asia. In addition most of the laboratories are situated at about the same latitude. It would also have been desirable to include laboratories at the extreme North/ South and at the equator. The choice has thus been made on the basis of those groups showing activity in the field where communication has been fast and where there were no requirements for non-disclosure agreements or other legal agreements that would hinder the possibility of disseminating the results. The study was undertaken with the mindset that the knowledge gained and gathered should be free to share and report in whichever context the individual participant sees fit. The devices were all provided free of charge and returned to the participants for safe keeping and future reference.

\subsection{Device performance}

After encapsulation the devices were all illuminated and $I-V$ curves were recorded until a stable performance was obtained. The performance for the devices exhibited a rather large spread but for the purpose of the experiment this was not viewed as a disadvantage as some laboratories would test the better performing devices and others would test devices of a lower performance. When plotting all the data (Fig. 3) it is evident that there is a

Table 3

Averages for the module parameters. The data is presented as average values \pm standard deviation

\begin{tabular}{lccc}
\hline Parameter & At Risø DTU & At recipient & Back at Risø DTU \\
\hline PCE (\%) & $1.09 \pm 0.24$ & $1.08 \pm 0.29$ & $1.16 \pm 0.23$ \\
$\boldsymbol{I}_{\mathbf{s c}}(\mathbf{m A})$ & $99.97 \pm 8.6$ & $96.52 \pm 27$ & $97.51 \pm 15$ \\
$\boldsymbol{V}_{\text {oc }}(\mathbf{V})$ & $3.35 \pm 0.30$ & $3.56 \pm 0.33$ & $3.47 \pm 0.28$ \\
FF (\%) & $38.5 \pm 3.9$ & $38.0 \pm 3.7$ & $40.0 \pm 2.6$ \\
\hline
\end{tabular}
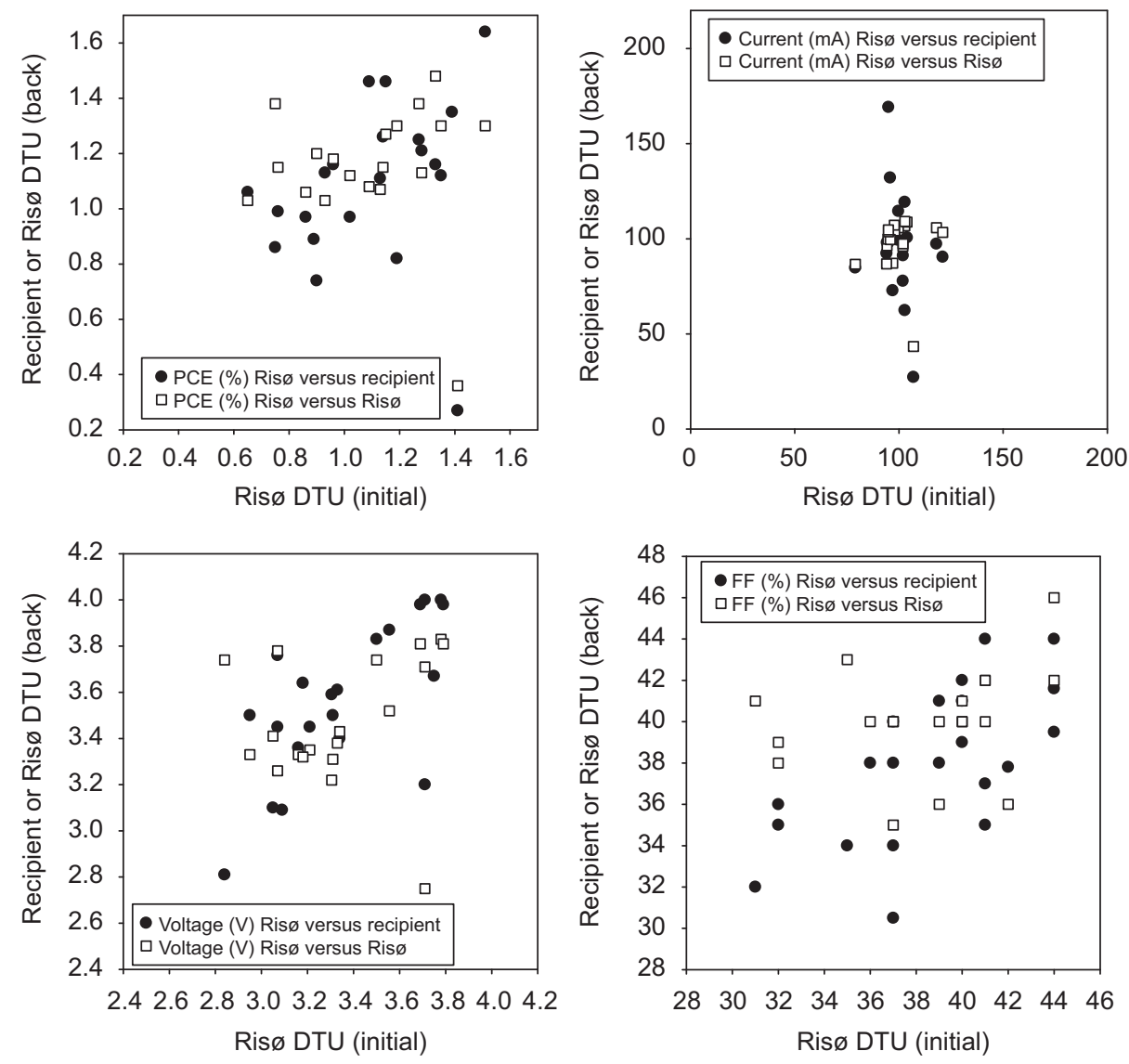

Fig. 3. Correlation of PCE, module current, module voltage and fill factor for all the devices employed in this round robin. 
Table 4

Correlation coefficients for the data plotted in Fig. 3. The data are presented as the value \pm one standard deviation.

\begin{tabular}{lcrrr}
\hline Plot & $\boldsymbol{y}(\mathbf{0})$ & \multicolumn{1}{l}{ Slope } & \multicolumn{1}{l}{$\boldsymbol{R}$} & \multicolumn{1}{c}{$\boldsymbol{R}^{\mathbf{2}}$} \\
\hline PCE (\%) Risø versus recipient & $0.73 \pm 0.30$ & $0.32 \pm 0.27$ & 0.27 & 0.07 \\
PCE (\%) Risø versus Risø & $1.17 \pm 0.24$ & $-0.01 \pm 0.22$ & 0.01 & 0.0001 \\
$\boldsymbol{I}_{\text {sc }}(\mathbf{m} \boldsymbol{A})$ Risø versus recipient & $152 \pm 72$ & $-0.56 \pm 0.71$ & 0.18 & 0.03 \\
$\boldsymbol{I}_{\mathbf{s c}}(\mathbf{m} \boldsymbol{A})$ Risø versus Risø & $84 \pm 40$ & $0.13 \pm 0.40$ & 0.08 & 0.007 \\
$\mathbf{V}_{\text {oc }}(\mathbf{V})$ Risø versus recipient & $0.99 \pm 0.61$ & $0.76 \pm 0.18$ & 0.69 & 0.48 \\
$\boldsymbol{V}_{\text {oc }}(\mathbf{V})$ Risø versus Risø & $2.84 \pm 0.71$ & $0.19 \pm 0.21$ & 0.20 & 0.04 \\
FF (\%) Risø versus recipient & $14.0 \pm 6.5$ & $0.62 \pm 0.17$ & 0.65 & 0.41 \\
FF (\%) Risø versus Risø & $33 \pm 5.8$ & $0.18 \pm 0.15$ & 0.27 & 0.07 \\
\hline
\end{tabular}

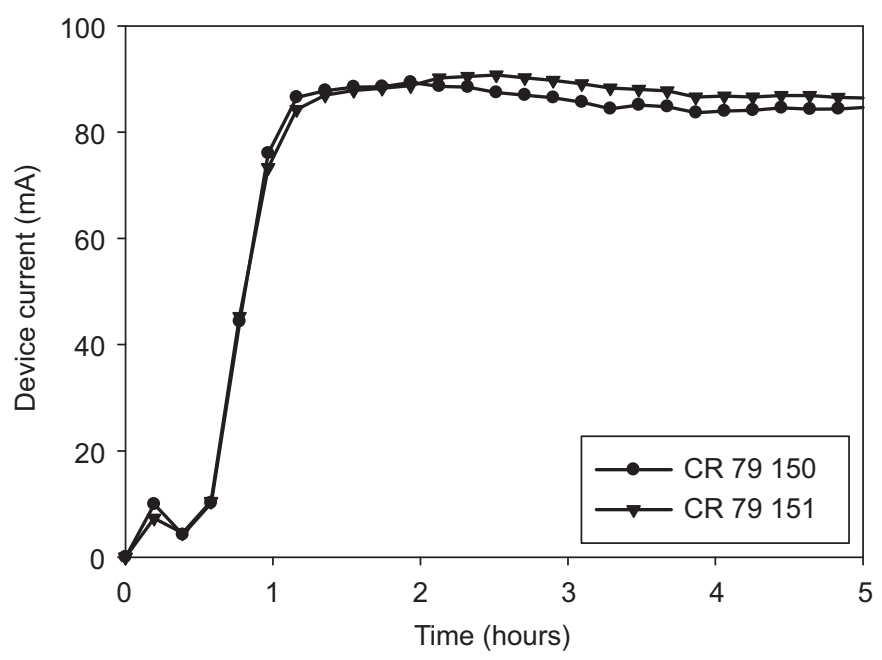

Fig. 4. Accelerated lifetime testing of two modules shown as the module current against time. The continuous illumination was done with solar simulator dedicated to accelerated testing with a high UV content. significant spread in the data presented in Table 2 and this is clear also from the averages presented in Table 3. No corrections were made for the change in current due to different light intensities employed in the 7 experiments carried out with natural sun light. This leads to a higher spread in current and also in voltage and to a lesser degree in power conversion efficiency (PCE) due to nonlinearity. When analyzing the data represented by this small set of devices with a large spread in parameters (PCE, $I_{\mathrm{sc}}, V_{\mathrm{oc}}$ and FF) due to both variation in the devices and variation in the conditions of testing by the different laboratories it is useful to start with looking at the spread observed before and after measurement with the recipient laboratory as this will reveal how reproducible device performance is over time and how well data with any degradation can be reproduced. In Table 3 it is evident that the average values of all the parameters were roughly constant with a small improvement in some parameters. The possibility that this is due to poor calibration can be ruled out on the basis that the experiment that shows the largest spread is the measurement of all devices at the same time before sending them to the participants (with recalibration between the measurement of each module). Upon return the devices had generally improved in performance and the spread was smaller. As can be seen from Table 1 the measurements of the cells upon return were all performed on different days and each measurement represents calibration of the solar simulator. Several ways to present the data was attempted and the best solution was found to be the correlation plots presented in Fig. 3.

The data for the correlations are shown in Table 4 and reveal a poor degree of correlation as expected. The FF and module voltage showed the highest degree of correlation. Since the module current is the parameter that is most sensitive to variations in incident light this is likely to hold a large part of the explanation. Generally the correlation between Risø DTU and the recipients was higher than the correlation between data recorded before transporting the modules and after return of the modules. A consistent observation was that the modules seemed to improve in performance during the study and the spread became less pronounced. This is also evident from visual inspection of Fig. 3. To rationalize the spread in the data and the increased
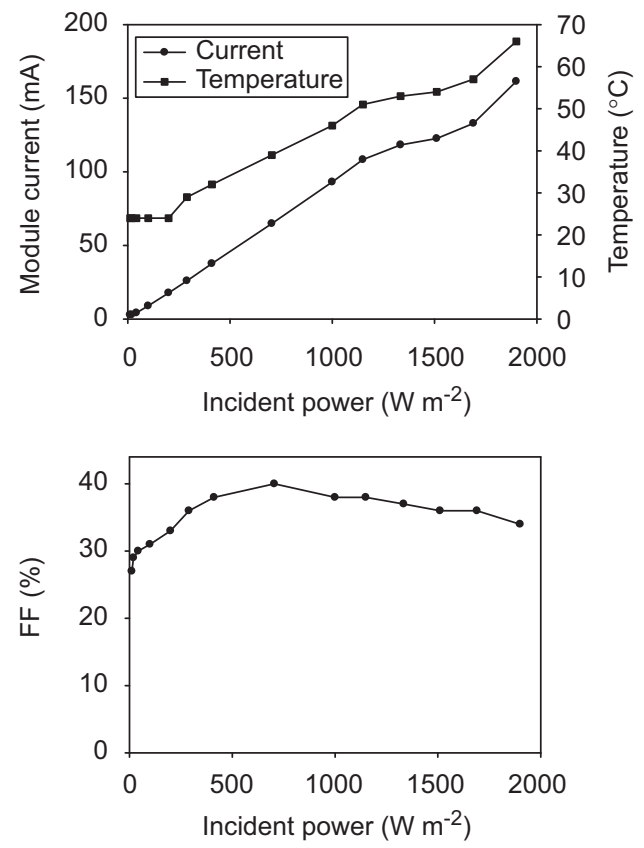

Fig. 5. Linearity of the PCE, $I_{\mathrm{sc}}, V_{\mathrm{oc}}$ and FF for a representative device (CR 79081 ) with respect to incident light intensity. The temperature was controlled by fan cooling but was subject to some variation as shown in the temperature plot. 
performance over time the dynamic nature of the devices can be taken into account. The performance does change over time and especially in the beginning as shown in Fig. 2. The devices were annealed to constant performance upon sending them out for the round robin, so the change over time that is assumed to be real is difficult to rationalize in absolute terms.

It is however reasonable to ascribe it to slow changes that take place under ambient conditions with relatively little incident light (i.e. during transport, temperature/humidty/pressure cycling, mechanical flexing and storage between measurements).

The devices seem quite stable towards handling except in the case of the module CR 79111 that was destroyed during a damp heat test and module CR 79157 that was subjected to the longest storage period followed by measurements using firstly a flashed light source that gave significantly lower performance than the measurement at Risø DTU. Subsequent transfer to a glove box (involving vacuum pumping cycles) significantly reduced the performance that was observed. This was confirmed upon receipt at Risø DTU. In order to establish if there is a general problem of subjecting these modules to vacuum or a glovebox environment, a module (CR 79 179) was measured and then transferred to a glovebox (through 3 pumping cycles) and then transferred back into the atmosphere followed by retesting. This showed a slight improvement of the performance and this was confirmed by repeating the experiment with an extra module (CR 79 202). In addition we repeated the experiment for both modules and left them in the glovebox for an additional $16 \mathrm{~h}$ and found that this did not alter the performance significantly (a slight improvement was observed). We thus conclude that the device failure in CR 79157 was atypical (catastrophic). It has however been included in the data analysis for completeness and represents the inevitable outlier.

The typical lifetime performance is shown in Fig. 4 where the module current is plotted as a function of time for two modules. $I-V$-curves were recorded every $10 \mathrm{~min}$ and illumination was carried out with a solar simulator for accelerated studies having a high UV content. The devices improve over the first hour in agreement with Fig. 2 and then reach stable operation. When considering the experiments as carried out in the different laboratories the analysis is not so straightforward due to the many different experimental conditions. The main variables in the experimental conditions were temperature and the light source (Table 2). Temperatures in the range $25-77^{\circ} \mathrm{C}$ were employed. Seven laboratories employed real sun light, three laboratories were unable to illuminate the full area of the modules and finally some laboratories had incident intensities different from $1000 \mathrm{~W} \mathrm{~m}^{-2}$. The differences in incident intensity influence the observed current which was only corrected for incident light intensity in one instance. Thus in addition to temperature, the linearity of the device with respect to incident power also has some importance. In order to rationalise these findings a representative module was evaluated with respect to both linearity and temperature dependence.

The incident light intensity was controlled by keeping the light source (Steuernagel KHS 1200) at constant power setting while changing the source-to-device distance. This also enabled a good degree of temperature control at the lower intensity settings. At high incident light intensity the temperature did increase and the linearity data shown in Fig. 5 thus include a temperature effect at the higher light intensities. It is evident that devices of the type employed in this study are subject to some variation with respect to incident light intensity. Most notably the voltage changes nonlinearly with incident light intensity leading to a sharp increase in performance at incident light intensities above $500 \mathrm{~W} \mathrm{~m}^{-2}$. The current is quite linear with respect to the incident light intensity. Some variation was observed at high incident light intensity that correlates well with the change in device temperature. The temperature dependence of the device performance was investigated in a separate experiment keeping the incident light intensity at a constant level of $1000 \mathrm{~W} \mathrm{~m}^{-2}$, AM1.5G. The devices operate best in the temperature range $0-80^{\circ} \mathrm{C}$. The current is linearly increasing from about $10-90{ }^{\circ} \mathrm{C}$ at a rate of about $25 \mu$ Adegree $^{-1}$. Below $0{ }^{\circ} \mathrm{C}$ and towards the lower temperatures the current drops quickly. The voltage has a maximum in the
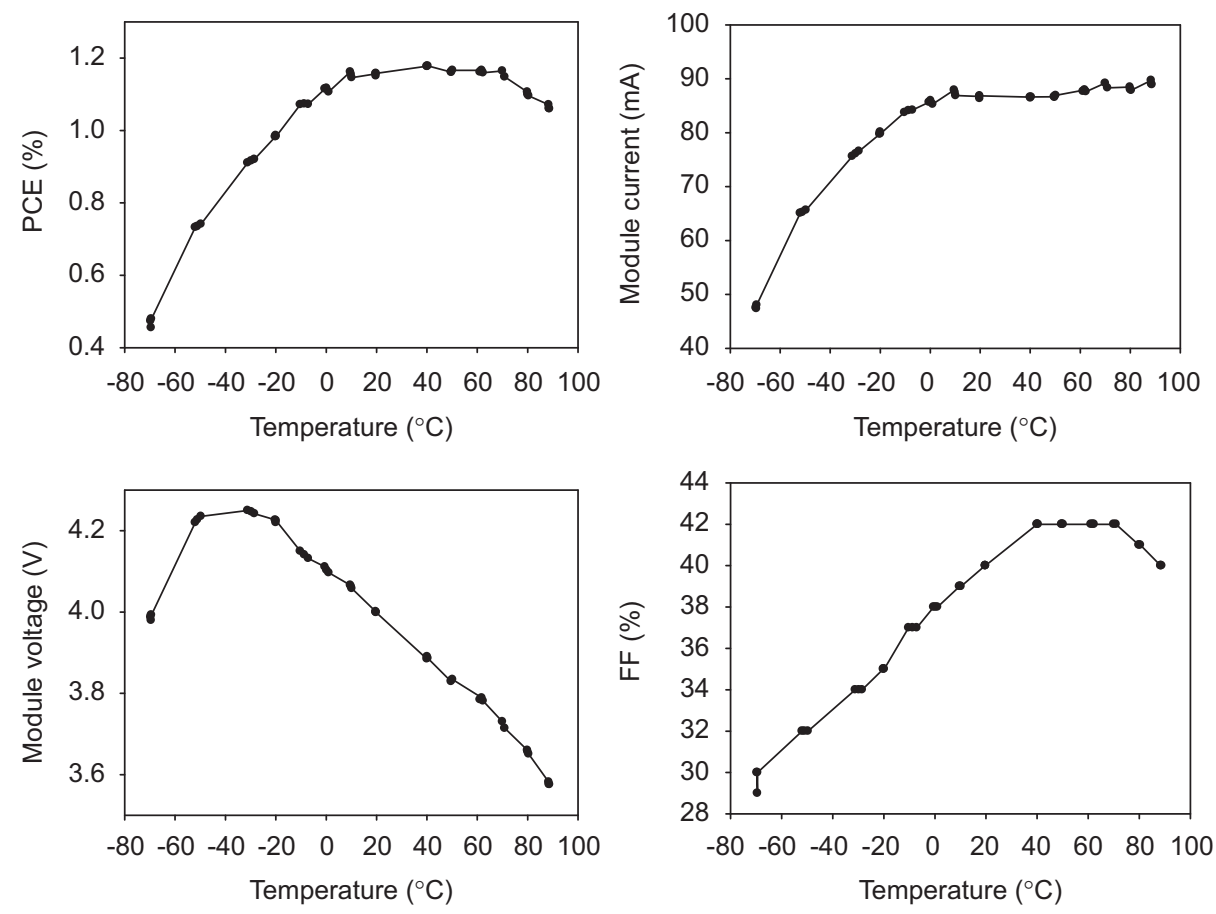

Fig. 6. Temperature dependence of the PCE, $I_{\mathrm{sc}}, V_{\mathrm{oc}}$ and $\mathrm{FF}$ for a representative device (CR 79081$)$. The incident light intensity was $1000 \mathrm{~W} \mathrm{~m}^{-2}$, AM1.5G. 
range $-50{ }^{\circ} \mathrm{C}$ to $-20^{\circ} \mathrm{C}$ and then starts to drop linearly with increasing temperature at a rate of $-5.7 \mathrm{mV}$ degree $^{-1}$. Drop in voltage and increase in current with temperature account for the broad operational maximum over a large temperature interval. With linearity and temperature dependence at hand, some of the variation in the performance parameters reported by the different participants can be rationalised. With these observations in mind it is clear that the technology is ready for RR or ILS. Some precautionary measures can however be identified and perhaps some guidelines can be highlighted. It is clear that some standard cell size is needed. This size has to be as large as possible to be meaningfully touted as a solar cell module but naturally has to be small enough for participants to illuminate it correctly. It seems that a module size of $10 \mathrm{~cm} \times 10 \mathrm{~cm}$ would be sufficient for all participants. The method of measurements has to be specified further and especially the temperature should be well defined. It is likely that either 25 or $70^{\circ} \mathrm{C}$ are rational choices as these are temperatures that can be practically reached with relative ease under a solar simulator with forced air cooling (using ambient air) or without cooling (heating due to illumination). Due to the dynamic nature of these devices it is likely that a short-time stability testing (e.g. $<24 \mathrm{~h}$ ) will be needed to ensure that the device is stable in performance. It is also likely that the mode of transportation (surface mail, air freight, etc.) might be influential on the slight alterations in device performance. This could be due to large humidity variations, large temperature variations, pressure changes and mechanical flexing. To further illuminate the observed improvement of the device performance over time it would be useful to cycle the same device or group of devices between laboratories in a traditional RR study where all laboratories make observations on the same devices albeit at different times. While this would have been the most desirable it would not have been possible in the current study (Fig. 6).

\section{Future points to address}

To summarize, the results of this study have shown that it is indeed feasible to carry out a RR or ILS using flexible large-area polymer solar cells using commercially available barrier film technology. Some issues that will need to be addressed in future studies are:

- the influence that transport type has on the devices,

- the need for a standard size for a flexible cell,

- the development of reliable electrical contacts,

- more rigid guidelines for the measurement protocol (temperature, humidity, light, stabilisation period)

- rigid encapsulation should be considered as it possibly has an advantage in terms of reproducibility,

- ensure that labs qualify and are ready to perform the measurements,

- make sure that the dynamic behaviour of polymer solar cells are accommodated in the protocol,

- the need for measuring the spectral response for the full module.

\section{Conclusions}

Polymer solar cell modules comprising eight serially connected stripes prepared by roll-to-roll coating methods were encapsulated using a standard barrier technology. Device modules were tested for performance in one laboratory (Risø DTU), transported to another participating laboratory and after testing the devices there were returned to the Risø DTU for re-testing. Eighteen laboratories distributed in Northern America, Europe and the Middle East participated in the study that took over 4 months. The evaluation of performance was achieved using both simulated sunlight and real sunlight. The main purpose was to demonstrate that it is possible with the current technology to share devices and obtain consistent data even over long periods of time. The enabling technology is the barrier material and the encapsulation that gives the devices stability sufficient for studies of this kind.

\section{Acknowledgements}

This work was supported by the Danish Strategic Research Council (DSF 2104-05-0052 and 2104-07-0022). Keith Emery at NREL is gratefully acknowledged for sharing his insights on round robin and ILS methodologies. Work at Linköping University is supported by the Swedish Energy Agency, the Knut and Alice Wallenberg Foundation and the Science Council. To the projects ENE2008-04373 and PIE-200860I134 from the Spanish Ministry of Science and Innovation (MICINN) and to the Consolider NANOSELECT project CSD2007-00041.

\section{References}

[1] M. Jørgensen, K. Norrman, F.C. Krebs, Stability/degradation of polymer solar cells, Sol. Energy Mater. Sol. Cells 92 (2008) 686-714.

[2] B.C. Thompson, J.M.J. Fréchet, Polymer-fullerene composite solar cells, Angew. Chem. Int. Ed. 47 (2008) 58-77.

[3] F.C. Krebs, Fabrication and processing of polymer solar cells. A review of printing and coating techniques, Sol. Energy Mater. Sol. Cells 93 (2009) 394-412.

[4] F.C. Krebs, M. Jørgensen, K. Norrman, O. Hagemann, J. Alstrup, T.D. Nielsen, J. Fyenbo, K. Larsen, J. Kristensen, A complete process for production of flexible large area polymer solar cells entirely using screen printing-first public demonstration, Sol. Energy Mater. Sol. Cells 93 (2009) 422-441.

[5] S. Heum Park, A. Roy, S. Beaupré, S. Cho, N. Coates, J.S. Moon, D. Moses, M. Leclerc, K. Lee, A.J. Heeger, Bulk heterojunction solar cells with internal quantum efficiency approaching 100\%, Nat. Photon., doi:10.1038/NPHOTON. 2009.69.

[6] H. Ossenbrink, K. Krebs, R.V. Steenwinckel, Results of the 1984/1985 international round robin calibration summit working group on technology, growth and employment, IEEE (1985) 943-944.

[7] J. Metzdorf, T. Wittchen, K. Heidler, K. Dehne, R. Shimokawa, F. Nagamine, H. Ossenbrink, L. Fornarini, C. Goodbody, M. Davies, K. Emery, R. Deblasio, Objectives and results of the PEP '87 Round-Robin Calibration of reference cells and modules, in: Proceedings of the 21st IEEE Photovoltaic Specialists Conference, Orlando, FL May 21-25, 1990, IEEE, New York, 1990, pp. 952-959.

[8] J. Metzdorf, T. Wittchen, K. Heidler, K. Dehne, R. Shimokawa, F. Nagamine, H. Ossenbrink, L. Fornarini, C. Goodbody, M. Davies, K. Emery, R. Deblasio, The results of the PEP '87 Round-Robin Calibration of reference cells and modules, Final Report, PTB Technical Report PTB-Opt-31, Braunschweig, Germany, November 1990, ISBN:3-89429-067-6.

[9] C.R. Osterwald, S. Anevsky, A.K. Barua, J. Dubard, K. Emery, D. King, J. Metzdorf, F. Nagamine, R. Shimokawa, N. Udayakumar, Y.X. Wang, W. Zaaiman, A. Zastrow, J. Zhang, Results of the PEP '93 intercomparison of reference cell calibrations and newer technology performance measurements, in: Proceedings of the 25th IEEE Photovoltaic Specialists Conference, Washington, DC, May 13-17, 1996, IEEE, New York, 1996, pp. 1263-1266.

[10] C.R. Osterwald, Results of 1992 ASTM cell and module measurement intercomparison, IEEE 1 (1993) 1102-1106.

[11] C.R. Osterwald, S. Anevsky, K. Bücher, A.K. Barua, P. Chaudhuri, J. Dubard, K. Emery, B. Hansen, D. King, J. Metzdorf, F. Nagamine, R. Shimokawa, Y.X. Wang, T. Wittchen, W. Zaaiman, A. Zastrow, J. Zhang, The world photovoltaic scale: an international reference cell calibration program, Prog. Photovolt: Res. Appl. 7 (1999) 287-297.

[12] T.R. Betts, R. Gottschalg, D.G. Infield, W. Kolodenny, M. Prorok, T. Zdanowicz, N. vand der Borg, H. de Moor, G. Friesen, A. Guerin de Montgareuil, W. Herrmann, Round robin comparison of European outdoor measurement systems, in: Proceedings of the 21st European Photovoltaic Solar Energy Conference, 4-8 September 2006, Dresden, Germany, pp. 2447-2451.

[13] W. Herrmann, S. Mau, F. Fabero, T. Betts, N. van der Borg, K. Kiefer, G. Friesen, W. Zaaiman, Advanced intercomparison testing of PV modules in European test laboratories, in: Proceedings of the 22nd European Photovoltaic Solar Energy Conference, 3-7 September 2007, Milan, Italy, pp. 2506-2510. 
[14] E.A. Katz, D. Faiman, S.M. Tuladhar, J.M. Kroon, M.M. Wienk, T. Fromherz, F. Padinger, C.J. Brabec, N.S. Sariciftci, Temperature dependence for the photovoltaic device parameters of polymer-fullerene solar cells under operating conditions, J. Appl. Phys. 90 (2001) 5343-5350.

[15] E.A. Katz, S. Gevorgyan, M.S. Orynbayev, F.C. Krebs, Out-door testing and long-term stability of plastic solar cells, Eur. Phys. J. Appl. Phys. 36 (2006) 307-311.

[16] R. Tipnis, J. Bernkopf, S. Jia, J. Krieg, S. Li, M. Storch, D. Laird, Large-area organic photovoltaic modules-fabrication and performance, Sol. Energy Mater. Sol. Cells 93 (2009) 442-446.

[17] G. Dennler, The value of values, Mater. Today 10 (2007) 56.

[18] Jan Gilot, Martijn M. Wienk, René A.J. Janssen, On the efficiency of polymer solar cells, Nat. Mater. 6 (2007) 704

[19] Moritz K. Riede, Toni Mueller, Bert Maennig, Karl Leo, Kristian O. SylvesterHvid, Birger Zimmermann, Michael Niggemann, Andreas Gombert, Comment on "Roles of donor and acceptor nanodomains in 6\% efficient thermally annealed polymer photovoltaics", Appl. Phys. Lett. 90 (2007) 163511; Moritz K. Riede, Toni Mueller, Bert Maennig, Karl Leo, Kristian O. SylvesterHvid, Birger Zimmermann, Michael Niggemann, Andreas Gombert, Comment on "Roles of donor and acceptor nanodomains in $6 \%$ efficient thermally annealed polymer photovoltaics", Appl. Phys. Lett. 92 (2008) 076101.

[20] G.P. Smestad, F.C. Krebs, C.M. Lampert, C.G. Granqvist, K.L. Chopra, X. Mathew, H. Takakura, Editorial, Reporting solar cell efficiencies in Solar Energy Materials and Solar Cells, Sol. Energy Mater. Sol. Cells 92 (2008) 371-373.

[21] F.C. Krebs, S.A. Gevorgyan, J. Alstrup, A roll-to-roll process to flexible polymer solar cells: model studies, manufacture and operational stability studies, J. Mater. Chem. 19 (2009) 5442-5451.

[22] F.C. Krebs, Polymer solar cell modules prepared using roll-to-roll methods: knife-over-edge coating, slot-die coating and screen printing, Sol. Energy Mater. Sol. Cells 93 (2009) 465-475.

[23] E.A. Katz, Outdoor measurements of organic solar cells, in: F.C. Krebs (Ed.), Organic Photovoltaics: A Practical Approach, SPIE, 2008, pp. 112-131.

[24] D. Berman, D. Faiman, EVA browning and the time-dependence of $I-V$ curve parameters on PV modules with and without mirror-enhancement in a desert environment, Sol. Energy Mater. Sol. Cells 45 (1997) 401-412.

[25] F.C. Krebs, Encapsulation of polymer photovoltaic prototypes, Sol. Energy Mater. Sol. Cells 90 (2006) 3633-3643.

[26] ISOS-1, 〈http://www.wikispaces.com/opvlifetime >. 